\section{Elevation of Serum Phosphate (Pi) Levels Associated with Blood Sampling in Some Teleosts}

\author{
Yuichi Sasayama,* Fumihiko Mizutani,* \\ Nobuo Suzuki,* and Chitaru Oguro*
}

(Received January 8, 1988)

During examinations of serum mineral concentrations in some teleosts, we noticed that in anesthetized fish with no respiration in air, the later the blood was taken, the higher the serum Pi level became. There were no meaningful changes in serum $\mathrm{Ca}, \mathrm{Mg}$ and $\mathrm{Na}$ levels. The following is a brief note on this phenomenon.

Goldfish Carassius auratus (av. $41 \mathrm{~g}$ ) and grasspuffer Takifugu niphobles (av. $39 \mathrm{~g}$ ) were anesthetized with neutralized MS-222 solution. Blood was successively collected from one individual initially from the gill by injuring the branchial artery with forceps, secondly from the dorsal aorta and finally from the heart by stabbing with a sharpened glass tube. These procedures took about $30 \mathrm{~min}$. The serum $\mathrm{Pi}$ concentration was measured according to a modified method of Fiske and Subbarow. ${ }^{1)}$ In both species, the $\mathrm{Pi}$ value in the cardiac blood was significantly higher than the levels in blood from the dorsal aorta and branchial artery (Fig. 1A). In the next experiment, blood was collected initially from the heart, secondly from the dorsal aorta, and finally from the heart again. This
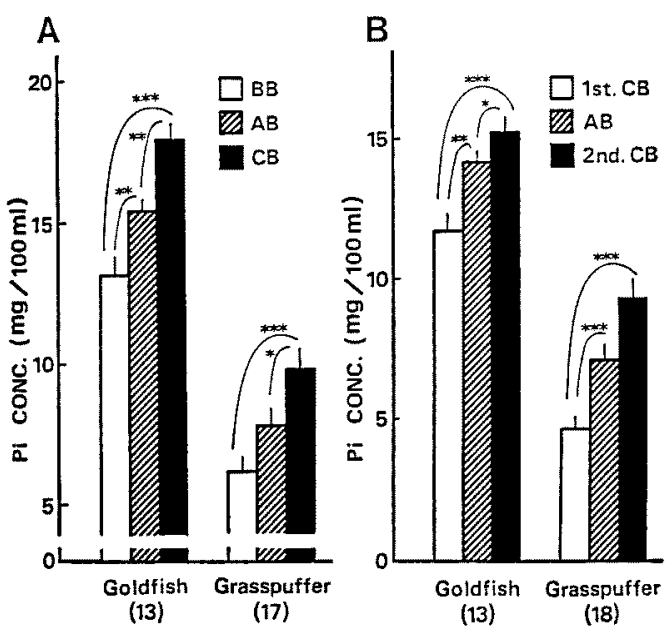

Fig. 1. A: Serum Pi levels in branchial blood (BB), arterial blood (AB) and cardiac blood (CB). $B$ : Serum Pi levels in CB taken early (1st CB), $A B$ and $C B$ taken later (2nd $C B$ ). Vertical bar at the top of each column indicates $+\mathrm{SE}$. The figures under the fish names show the numbers of animals used.
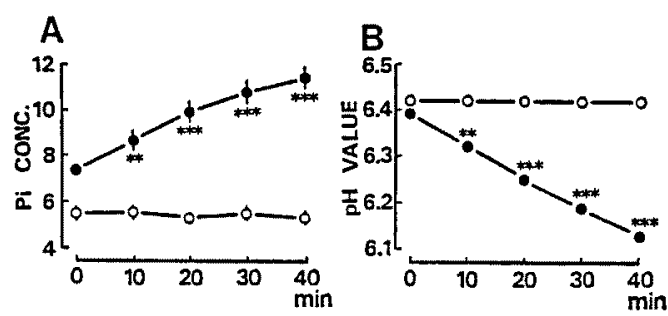

Fig. 2. A: Changes in serum Pi levels. B: Changes in serum $\mathrm{pH}$ values. (O) represents the blood taken from unanesthetized goldfish in water, and (e) that taken from anesthetized fish exposed to air. Each symbol shows the mean for 9 animals.

In both Figs., *, ** and *** indicate significant differences of $(p<0.05),(p<0.005)$ and $(p<0.001)$, respectively, by paired-sample $t$-test. In Fig. 2, the asterisk shows the difference from the initial value.

also took about $30 \mathrm{~min}$. In both species, the $P i$ value in the serum taken finally from the heart was the highest, and the level in the serum obtained initially, the lowest (Fig. 1B). On the other hand, in unanesthetized goldfish which can respire in water and anesthetized goldfish which is exposed to air and can not respire, blood was taken by means of cannulation with a silicone tube to the arterial bulb every $10 \mathrm{~min}$ for $40 \mathrm{~min}$. The serum Pi level was elevated only in anesthetized fish exposed to air (Fig. 2A). In this experiment, the serum $\mathrm{pH}$ level was also checked. It was determined after the centrifugation of the blood, with lithmus paper because of the small sample volume. The $\mathrm{pH}$ value in this way was lower than that determined by using a flow-through type electrode. Nevertheless, the serum $\mathrm{pH}$ level declined gradually but significantly only in the anesthetized fish (Fig. 2B).

Taking the characteristics ${ }^{2,3)}$ of fish respiration into consideration, it seems that this phenomenon is related to respiratory acidosis. The present observation shows that in teleosts, special care must be taken when examining the effects of various treatments on the blood $P i$ level.

The present study was supported in part by Grantsin-Aid from the Ministry of Education, Science and Culture of Japan (No. 62540566 to Y.S.).

\section{References}

1) C. H. Fiske and Y. Subbarow: J. Biol. Chem., $66,375-400$ (1925).

2) C. Grigg: in "Chemical Zoology" (eds. by M. Florkin and B. T. Scheer), Academic Press, New York, 1974, pp. 331-368.

3) C. Albers: in "Fish Physiology IV" (eds. by W. S. Hoar and D. J. Randall), Academic Press, New York, 1970, pp. 173-208.

* Faculty of Science, Toyama University, Toyama 930, Japan（笹山雄一，水谷文彦，鈴木信雄，小黑千足： 富山大学理学部). 